\title{
Critical appraisal of the potential use of cannabinoids in cancer management
}

This article was published in the following Dove Press journal:

Cancer Management and Research

29 August 2013

Number of times this article has been viewed

\section{Belinda J Cridge \\ Rhonda J Rosengren}

Department of Pharmacology and Toxicology, University of Otago,

Dunedin, New Zealand
Correspondence: Rhonda J Rosengren Department of Pharmacology and Toxicology, University of Otago, PO Box 9/3, Dunedin 9054,

New Zealand

Tel +64 3479 9|4l

Email rhonda.rosengren@otago.ac.nz
Abstract: Cannabinoids have been attracting a great deal of interest as potential anticancer agents. Originally derived from the plant Cannabis sativa, there are now a number of endo-, phyto- and synthetic cannabinoids available. This review summarizes the key literature to date around the actions, antitumor activity, and mechanisms of action for this broad range of compounds. Cannabinoids are largely defined by an ability to activate the cannabinoid receptors $-\mathrm{CB}_{1}$ or $\mathrm{CB}_{2}$. The action of the cannabinoids is very dependent on the exact ligand tested, the dose, and the duration of exposure. Some cannabinoids, synthetic or plant-derived, show potential as therapeutic agents, and evidence across a range of cancers and evidence in vitro and in vivo is starting to be accumulated. Studies have now been conducted in a wide range of cell lines, including glioma, breast, prostate, endothelial, liver, and lung. This work is complemented by an increasing body of evidence from in vivo models. However, many of these results remain contradictory, an issue that is not currently able to be resolved through current knowledge of mechanisms of action. While there is a developing understanding of potential mechanisms of action, with the extracellular signal-regulated kinase pathway emerging as a critical signaling juncture in combination with an important role for ceramide and lipid signaling, the relative importance of each pathway is yet to be determined. The interplay between the intracellular pathways of autophagy versus apoptosis is a recent development that is discussed. Overall, there is still a great deal of conflicting evidence around the future utility of the cannabinoids, natural or synthetic, as therapeutic agents.

Keywords: cancer, cannabinoid, endocannabinoid, tetrahydrocannabinol, JWH-133, WIN$55,212-2$

\section{Introduction}

The cannabinoids are a class of over 60 compounds derived from the plant Cannabis sativa, as well as the synthetic or endogenous versions of these compounds. ${ }^{1}$ Cannabis has been used as a medicinal and recreational drug for many centuries, but its psychoactive properties have led to legal regulations around access and use in most countries. ${ }^{2}$ Despite this, scientific research into both natural and synthetic cannabinoids has continued. Studies are now being conducted on the potential efficacy of cannabinoids, both natural and synthetic, as anticancer agents and their possible mechanisms of action.

The first cannabinoid to be intensively studied was trans $-\Delta^{9}$-tetrahydrocannabinol ( $\Delta^{9}$-THC) which was first isolated in the 1960s. ${ }^{3}$ While several other active compounds, notably $\Delta^{8}$-THC, cannabinol, cannabidiol, and cannabicyclol, were able to be isolated, it was not until 1992 that an analogous endogenous ligand - anandamide 
(AEA) - was identified (Table 1). ${ }^{4}$ This discovery was closely followed by the identification of the endogenous ligands 2-arachidonoyl glycerol (2-AG), 2-arachidonyl glyceryl ether (2-AGE), $O$-arachidonoyl ethanolamine (virodhamine), and $\mathrm{N}$-arachidonoyl dopamine (NADA). ${ }^{5}$ As the names of these compounds suggest, they are derivatives of the parent compound arachidonic acid, which is an important lipidsignaling molecule and a key component of the inflammatory pathway. ${ }^{6}$ The endocannabinoids mimic the actions of $\Delta^{9}$-THC in mouse behavioral tests, interfere with learning and memory, activate the hypothalamic-pituitary-adrenal axis, decrease hypothalamus prolactin secretion, decrease intraocular pressure, cause hypotension and bradycardia, and modulate the immune system. ${ }^{7,8}$

The first cannabinoid receptor was discovered in $1988^{9}$ and then cloned in $1990 .{ }^{10}$ This was followed in 1993 with the discovery of a second form of the receptor, which shares $44 \%$ amino acid identity and a distinct yet similar binding profile for cannabinoid compounds. ${ }^{11}$ This development led to the current terminology of $\mathrm{CB}_{1}$, for the original receptor form, and $\mathrm{CB}_{2} \cdot \mathrm{CB}_{1}$ receptors are found throughout the brain, spleen, eye, testis, and uterus, ${ }^{10-12}$ whereas $\mathrm{CB}_{2}$ receptors are associated with the cells and organs of the immune system as well as tumor cells. ${ }^{11,13,14}$ Both receptors are part of the G-protein-coupled receptor (GPR) superfamily. In general, cannabinoid agonists do not show a great deal of selectivity between $\mathrm{CB}_{1}$ and $\mathrm{CB}_{2}$ binding; however, newly developed synthetic antagonists are now available that allow the experimental delineation of $\mathrm{CB}_{1}$ versus $\mathrm{CB}_{2}$ effects. On a general level, $\mathrm{CB}_{1}$ binding is responsible for the psychoactive properties of the cannabinoid agonists, and $\mathrm{CB}_{2}$ binding mediates immune effects. ${ }^{5}$ This is discussed in more detail in later sections. The first cannabinoid-receptor antagonist was released in 1994 -SR141716 (rimonabant). ${ }^{15}$
Originally designed as a treatment for obesity, it has seen extensive use as a pharmacological tool in assessing agonist actions through the $\mathrm{CB}_{1}$ receptor; however, the classification of this compound as a pure antagonist is likely to be misleading, and its more recent classification as a selective $\mathrm{CB}_{1}$-receptor inverse agonist is more accurate. Following the discovery of SR141716, a range of antagonists and inverse agonists has been developed, including SR144528, which is an inverse agonist at the $\mathrm{CB}_{2}$ receptor ${ }^{16-18}$ (Table 1).

In the 20 years since the discovery of the $\mathrm{CB}_{2}$-receptor isoform, there have been a number of anomalous results that suggest that cannabinoid agonists exert actions beyond those mediated by $\mathrm{CB}_{1}$ or $\mathrm{CB}_{2} \cdot{ }^{19}$ This has led to the suggestion that there may be more isoforms of the $\mathrm{CB}$ receptor still to be identified; possible candidates include GPR119, GPR55, and GPR $18 .{ }^{20}$ Of the three, GPR55 has the largest body of evidence, suggesting it should be renamed as a cannabinoid receptor, but low-sequence homology with $\mathrm{CB}_{1}$ and $\mathrm{CB}_{2}$ along with conflicting results in agonist-binding studies means that it has not yet been fully reclassified. ${ }^{20,21}$ Both GPR119 and GPR18 show evidence of cannabinoid binding, but the results are not sufficiently robust to rename either protein as a cannabinoid-receptor isoform. ${ }^{5,20,21}$ The transient receptor potential cation channel subfamily V member 1 (TRPV1) receptor has also been proposed as a possible cannabinoid isoform. The endogenous cannabinoids AEA and NADA are potent TRPV1 agonists, and a raft of evidence has established the in vivo activity of these compounds unique to TRPV1 signaling. ${ }^{22}$ However, TRPV1 is an ionotropic receptor rather than a GPR, which means it does not meet one of the five criteria established for classification as a cannabinoid receptor. The ruling body, the International Union of Basic and Clinical Pharmacology, is seeking further evidence before renaming TRPV1 as a possible ionotropic cannabinoid $\mathrm{CB}_{3}$ receptor. ${ }^{20}$

Table I A selection of cannabinoid receptor ligands and their specificities

\begin{tabular}{|c|c|c|c|c|c|}
\hline Ligand & Source & Action & Specificity & $K_{i} C B_{1}(n M)$ & $K_{i} C B_{2}(n M)$ \\
\hline$\Delta^{9}-\mathrm{THC}$ & Plant-derived & Nonspecific agonist & $\mathrm{CB}_{1}>\mathrm{CB}_{2}$ & $5-80$ & $3-75$ \\
\hline Cannabidiol & Plant-derived & Low-to-no receptor affinity & & & \\
\hline Anandamide (AEA) & Endogenous & Nonspecific agonist & $\mathrm{CB}_{1} \gg \mathrm{CB}_{2}$ & $61-543$ & $279-1,940$ \\
\hline 2-arachidonoylglycerol (2-AG) & Endogenous & Nonspecific agonist & $\mathrm{CB}_{1}>\mathrm{CB}_{2}$ & $58-472$ & $\mid 45-1,400$ \\
\hline R-(+)-Met-anandamide & Synthetic & Nonspecific agonist & $C B_{1} \gg C_{2}$ & $18-28$ & $815-868$ \\
\hline WIN-55,2I2-2 & Synthetic & Nonspecific agonist & $C B_{1}=C B_{2}$ & $2-123$ & $0.3-16$ \\
\hline $\mathrm{HU}-2 \mathrm{IO}$ & Synthetic & Nonspecific agonist & $C B_{1}=C B_{2}$ & $0.06-0.7$ & $0.2-0.52$ \\
\hline JWH-I33 & Synthetic & Selective agonist & $\mathrm{CB}_{2}$ & 677 & 3.4 \\
\hline SRI4I7I6 & Synthetic & Selective antagonist & $\mathrm{CB}_{1}$ & 1.8 & 514 \\
\hline SRI44528 & Synthetic & Selective antagonist & $\mathrm{CB}_{2}$ & $50-10,000$ & $0.3-6$ \\
\hline
\end{tabular}

Notes: $K_{i}$ values are reported based on reported values for the in vitro displacement of $\left[{ }^{3} \mathrm{H}\right] \mathrm{CP} 55,940\left(\mathrm{CB}_{1}\right)-$ or $\left[{ }^{3} \mathrm{H}\right] \mathrm{HU} 243\left(\mathrm{CB}_{2}\right)$-binding sites.

Abbreviation: THC, tetrahydrocannabinol. 


\section{Physiological functions of cannabinoids \\ Synthesis}

The endocannabinoids (AEA and 2-AG) are generally accepted to be synthesized on demand following receipt of an intracellular signal, such as cellular depolarization or $\mathrm{Ca}^{2+}$-dependent receptor stimulation. However, there is also mounting evidence to suggest that AEA may be stored to some degree within the adiposome cellular compartment. ${ }^{23}$ AEA is synthesized from lipid precursors via enzymatic hydrolysis of $N$-acyl-phosphatidylethanolamines (NAPEs). This reaction is catalyzed by phospholipase $\mathrm{D}$ (PLD), which shows selectivity for this reaction. ${ }^{24,25}$ PLD activity is regulated by cellular depolarization, by activation of the NMDA, and by the metabotropic classes of glutamate receptor. ${ }^{24}$ The NAPE precursor is derived from the transfer of arachidonic acid from phosphatidylcholine to phosphatidylethanolamine, a reaction catalyzed by an $\mathrm{N}$-acetyltransferase isoform. This transfer is modulated by the presence of $\mathrm{Ca}^{2+}$ and cyclic adenosine monophosphate (cAMP). ${ }^{24}$

The synthesis of 2-AG may theoretically proceed through several putative pathways, but consensus favors hydrolysis of membrane lipids through PLC to produce 1,2-diacylglycerol. ${ }^{26}$ 1,2-diacylglycerol can then be converted through the action of diacylglycerol lipase to the 2-AG molecule. Although 2-AG concentrations are linked to membrane depolarization, similar to AEA, the underlying control mechanisms are thought to be different, as intracellular AEA concentrations cannot be directly linked to $2-A G$ concentrations. ${ }^{24,26}$

\section{Degradation}

Once synthesized, the endocannabinoids act locally, either by interacting with plasma-bound cannabinoid receptors on the cell where they were produced or on directly neighboring cells. Signaling is terminated by the uptake of the endocannabinoid by a regulated mechanism facilitated by the AEA membrane transporter. ${ }^{25}$ Following uptake, the cannabinoid is hydrolyzed by the fatty acid amide hydrolase and the monoacylglyceride hydrolase. Fatty acid amide hydrolase is a non-specific enzyme which catalyzes the hydrolysis of numerous fatty acid molecules and as such is widely distributed around the body. ${ }^{27}$ Monoacylglyceride hydrolase, in contrast, is limited in its distribution to the nerve terminals of specific brain neurons. ${ }^{28}$

\section{Intracellular actions}

Both forms of the traditional cannabinoid receptor, $\mathrm{CB}_{1}$ and $\mathrm{CB}_{2}$, are G-protein-linked. This means their activation results in inhibition of adenylate cyclase which is blocked by pertussis toxin. This causes a decrease in cellular cAMP, activation of the p38 mitogen-activated protein kinase (MAPK) pathway, and/or activation of ion channels. Evidence suggests that different conformational forms of GPRs allows downstream activities to be specifically modulated based on the individual ligand that binds and activates the receptor (Table 2) ${ }^{29}$ This specificity of action has been observed for the $\mathrm{CB}_{1}$ receptor whereby the antagonist WIN-55,212-2 activated different $\mathrm{G}_{\mathrm{i} / 0}$ subtypes with differing sensitivities ${ }^{25,26,30,31}$ (Table 2).

\section{Systemic actions of cannabinoids}

The most obvious action of the cannabinoids is in the brain. Receptors and synthesis and degradation enzymes of the cannabinoids are found distributed throughout the central nervous system. ${ }^{32}$ Ingestion of cannabinoids results in mood alterations, sedation, increased appetite, hallucinations, and impairment of memory, coordination, and executive function..$^{33}$ At higher concentrations, cannabinoids produce analgesia. ${ }^{34}$ The majority of these effects are purported to be mediated through alterations of signaling through the glutamatergic neurons or $\gamma$-aminobutyric acid (GABA) neurons located in different areas of the brain. ${ }^{35}$ Cannabinoid action in the motor cortex, basal ganglia, or cerebellum leads to impaired motor performance and ataxia. ${ }^{36,37}$ The extreme effect of catalepsy is thought to be mediated by action at the globus pallidus, striatal spiny neurons, and cortical glutamate neurons. ${ }^{38,39}$ The analgesic properties of

Table 2 Intracellular action of cannabinoids

\begin{tabular}{|c|c|c|}
\hline $\begin{array}{l}\text { Second } \\
\text { messenger }\end{array}$ & Direct effect & Cellular result \\
\hline $\mathrm{G}_{\mathrm{i} / 0}$ & $\begin{array}{l}\text { Inhibits adenylate } \\
\text { cyclase }\end{array}$ & $\begin{array}{l}\text { Decreased cAMP, inhibition } \\
\text { of phosphokinase A (PKA) }\end{array}$ \\
\hline $\mathrm{G}_{\mathrm{s}}$ & $\begin{array}{l}\text { Stimulates adenylate } \\
\text { cyclase }\end{array}$ & $\begin{array}{l}\text { Increase cAMP, activation } \\
\text { of PKA }\end{array}$ \\
\hline$G_{q}$ & $\begin{array}{l}\text { Modulation of } \mathrm{Ca}^{2+} \\
\text { channel }\end{array}$ & $\begin{array}{l}\text { Changes in intracellular } \\
\mathrm{Ca}^{2+}\end{array}$ \\
\hline $\mathrm{G}_{\mathrm{i} / 0}$ & $\begin{array}{l}\text { Activation of G-protein- } \\
\text { coupled inwardly } \\
\text { rectifying potassium } \\
\text { channels (GIRKs) }\end{array}$ & Increase in intracellular K \\
\hline $\mathrm{G}_{\mathrm{i} / 0}$ & Modulation of ERKI/2 & $\begin{array}{l}\text { Modulation of p38 } \\
\text { MAPK and JNK pathways } \\
\text { thereby regulating cellular } \\
\text { proliferation, differentiation, } \\
\text { movement and death }\end{array}$ \\
\hline
\end{tabular}

Notes: Data from. ${ }^{19,20,25}$

Abbreviations: ERK, extracellular signal-regulated kinase; MAPK, mitogen-activated protein kinase; JNK, c-Jun $\mathrm{NH}(2)$-terminal protein kinase; cAMP, cyclic adenosine monophosphate. 
the cannabinoids are linked to action on GABA neurons in the periaqueductal grey and rostroventral medulla regions and the ventral posterolateral nucleus of the thalamus. ${ }^{40} \mathrm{CB}_{1}$ receptors are also present in the spinal cord and on peripheral nociceptors, where they can mediate neuropathic pain and inflammation. ${ }^{41-43}$ However, recently there has been a degree of controversy around the specificity of antibodies used in several cannabinoid-receptor immunolocalization studies. ${ }^{44}$ Therefore, it is possible that the results regarding the exact distribution of the receptor in anatomical substructures are likely to be challenged and refined over the coming years.

The role of cannabinoids as modulators of the immune system is becoming more obvious. $\mathrm{CB}_{1}$ receptors are located on $\mathrm{T}$ lymphocytes ${ }^{45}$ whereas $\mathrm{CB}_{2}$ receptors, historically associated with immune function, are located in human B cells, natural killer cells, monocytes, polymorphonuclear neutrophils, and T cells. ${ }^{46}$ In general, cannabinoid agonists are associated with decreased immune function and decreased release of inflammatory mediators, such as interleukin (IL)-1, IL-2, IL-6, and IL-12. ${ }^{47}$ However, this effect is complicated by duration of exposure and dose. ${ }^{46,48}$

\section{Role of cannabinoids in cancer}

Two therapeutic avenues exist for the development of cannabinoids as anticancer agents. As antiemetic and analgesic compounds, this class of compounds has been explored in terms of palliative care. More recently, cannabinoid agonists and antagonists have been screened for potential direct antitumorigenic properties.

\section{Palliative care}

Cannabinoids can play an important role in the palliation of pain, nausea, vomiting, and appetite for cancer patients; however, this is beyond the scope of this review. The palliative uses of cannabinoids have been reviewed elsewhere. ${ }^{49-51}$

\section{Antitumorigenic properties}

Cannabinoids are not yet approved for the treatment of tumor progression, although their antitumorigenic effects have been known for over 30 years. ${ }^{52}$ Cannabinol and $\Delta^{8}$-THC inhibited tumor growth in a mouse model of Lewis lung adenocarcinoma after 20 days of treatment, whereas cannabidiol or $\Delta^{9}$-THC failed to show any effect. ${ }^{52}$ Since this pioneering study, a vast range of cancer cell and tumor models have been used to evaluate the possible efficacy and mechanisms of cannabinoid antitumor activity. This work is supported by findings that the endocannabinoid system may be altered during disease states. Significant levels of the cannabinoid receptor are found in prostate, breast, leukemia, melanoma, and thyroid cell lines, as well as colorectal and hepatocellular carcinoma tissue. ${ }^{53-58}$ Of particular significance is the fact that in prostate cancer cell lines, there is evidence that the expression of both $\mathrm{CB}_{1}$ and $\mathrm{CB}_{2}$ is elevated compared to normal prostate cells. ${ }^{53}$ Similarly, in lymphoma and breast cancer tissue, as well as some derived cell lines, $\mathrm{CB}_{1}$ and $\mathrm{CB}_{2}$ are overexpressed..$^{59,60}$ The degree of increased expression correlates with tumor aggression and progression, an effect also reported in human astrocytes. ${ }^{54,61}$ In contrast, McKallip et al found that Michigan Cancer Foundation (MCF)-7 and MDA-MB-231 breast cancer cell lines showed very low levels of $\mathrm{CB}_{1}$ expression, and $\mathrm{CB}_{2}$ was below detectable levels, as determined by reverse-transcription polymerase chain reaction. ${ }^{62}$ One reason for the reported discrepancies may be inaccuracies in reporting the subcellular localization of the receptor. It is probable that extensive trafficking between the plasma membrane and internal compartments, such as lysosomes, occurs, and that this is altered by exposure to cannabinoid agonists ${ }^{59,63-69}$ (Table 3).

\section{Anticancer actions of specific compounds Endo- and phytocannabinoids ( $\Delta^{9}$-THC, AEA, cannabidiol)}

The primary active constituent of cannabis, $\Delta^{9}$-THC, has been investigated in a number of in vitro- and in vivo-based systems. Overall, some efficacy has been recorded in breast, prostate, glioma, lymphoma, and pancreatic cancer cell lines. In contrast, there are reports of pro-cancerous activity in breast, bronchial, hepatoma, and lung cell lines (Table 3 ).

Results are not clear-cut as to whether $\Delta^{9}$-THC causes pro- or antiproliferative effects in breast cancer cells. A study of $\Delta^{9}$-THC in MCF-7 and MDA-MB-231 cells $(\leq 5 \mu \mathrm{M})$ reported proliferation in response to cannabinoid treatment. ${ }^{62}$ This finding is supported by the work of Takeda et al, who also documented a proliferative response to $\Delta^{9}$-THC in MCF-7 cells. ${ }^{70}$ In contrast, McAllister et al reported decreased proliferation in MDA-MB-231 and MDAMB-468 cells, while studies in EVSA-T cells also showed $\Delta^{9}$-THC inhibited cell growth. ${ }^{71}$ In MCF-7 cells, von Bueren et al reported that $\Delta^{9}$-THC did not induce cell proliferation at concentrations up to $1 \mathrm{mM}$, but did inhibit $17 \beta$-estradiol (100 nM)-induced proliferation at concentrations above $1 \mu \mathrm{M} .^{72}$ In mouse models of breast cancer, contradictory results have also been reported. In a xenotransplant model of 4T1 paw cells in BALB/c mice, an increase in tumor size was recorded following $\Delta^{9}$-THC $(25 \mathrm{mg} / \mathrm{kg}$, intraperitoneally, 21 days).$^{62}$ In contrast, in MMTV-neu mice that showed 
Table 3 Cannabinoid action in various cancer cell lines

\begin{tabular}{|c|c|c|c|}
\hline Cell type/line & Source & Cannabinoid & Effect \\
\hline ND & Bronchial epithelium & $\mathrm{THC}$ & Increased proliferation \\
\hline ND & Endothelial & THC & Increased proliferation \\
\hline $\mathrm{NCl}-\mathrm{H} 292$ & Lung & THC & Increased proliferation \\
\hline Нера & Hepatoma & THC & Increased proliferation \\
\hline A549 & Lung & THC & Increased proliferation \\
\hline A549, H460, H358 & Lung & CBD & Decreased invasion \\
\hline LNCaP & Prostate & R-(+)-Met & Increased proliferation \\
\hline PC-3, LNCaP & Prostate & AEA, R-(+)-Met, THC & Decreased proliferation \\
\hline LNCaP & Prostate & WIN-55,2I $2-2$ & Decreased proliferation \\
\hline MCF-7 & Breast & AEA, 2-AG, HU-2I0 & Decreased proliferation \\
\hline MCF-7, MDA-MB-23I, MDA-MB-436 & Breast & $\begin{array}{l}\text { THC, Met-F-AEA, WIN-55,2/2-2, } \\
\text { JWH-I } 33\end{array}$ & Decreased proliferation \\
\hline $4 \mathrm{TI}$ & Mouse mammary & THC & Decreased proliferation \\
\hline TSA-EI & Mouse breast cancer & Met-F-AEA & Decreased proliferation \\
\hline U87-MG, U373 & Glioma & CBD & Decreased proliferation \\
\hline C6 & Rat glioma & THC, JWH-I22, WIN-55,2I 2-2 & Decreased proliferation \\
\hline U25I, SF-I 26 & Glioblastoma & THC & Decreased proliferation \\
\hline \multirow[t]{2}{*}{ GBM } & Glioblastoma & THC, WIN-55,2I 2-2 & Decreased proliferation \\
\hline & Human astrocytoma & JWH-I33 & Decreased proliferation \\
\hline KiMol & K-ras-transformed FRTL-5 thyroid & Met-F-AEA & Decreased proliferation \\
\hline EL-4 & Thymoma/lymphoma & $\mathrm{HU}-210$ & Decreased proliferation \\
\hline PDV-C57 & Mouse skin carcinoma & JWH-I33, WIN-55,2। $2-2$ & Decreased proliferation \\
\hline HUVEC & Umbilical vein & JWH-I33 & Decreased proliferation \\
\hline
\end{tabular}

Notes: Data from. ${ }^{55-58}$

Abbreviations: ND, not described; THC, tetrahydrocannabinol; CBD, cannabidiol; MCF, Michigan Cancer Foundation; R-(+)-Met, R-(+)-methanandamide; AEA, anandamide; 2-AG, 2-arachidonoylglycerol; Met-F-AEA, Met-fluoro-anandamide; GBM, glioblastoma multiforme; HUVEC, human umbilical vein endothelial cell.

spontaneous development of mammary tumors, $\Delta^{9}$-THC ( $0.5 \mathrm{mg} / \mathrm{animal} /$ day, peritumorally, 90 days) decreased the size of mammary tumors, the occurrence of new spontaneous tumors, and the degree of metastasis to the lungs. ${ }^{73}$ These results indicate that the role of compounds such as $\Delta^{9}$-THC is not well understood, and its effects are possibly regulated by a range of factors that are yet to be determined.

In prostate cancer cell lines, $\Delta^{9}$-THC and 2-AG increased cellular proliferation, whereas AEA had the opposite effect. Sánchez et al documented increased proliferation of $\mathrm{LNCaP}$ and PC 3 cells following treatment with $\Delta^{9}$-THC $(50 \mathrm{nM}){ }^{74,75}$ In the same cell lines, AEA decreased proliferation. Mimeault et al evaluated AEA in PC3, LNCaP, and DU145 cell lines, and showed a significant decrease in cell viability at concentrations above $2 \mu \mathrm{M} .{ }^{76}$ Similarly, Nithipatikom et al documented a decrease in PC-3 cellular proliferation at AEA concentrations above $1 \mu \mathrm{M}$, whereas $2-\mathrm{AG}$ at similar concentrations caused an increase in cellular growth. ${ }^{77}$

In glioma cell lines, almost all studies show that cannabinoids decrease cell proliferation. $\Delta^{9}$-THC has been investigated in C6, SF126, U87-MG, U251, SF188, and U373-MG cell lines at concentrations of 1-2 $\mu \mathrm{M}$. Results showed a consistent decrease in cell viability independent of cell line. ${ }^{78,79}$ In U87 and U373 cells, cannabidiol inhibited cell proliferation, but the half-maximal inhibitory concentration
$\left(\mathrm{IC}_{50}\right)$ value for this effect was unusually high at $25 \mu \mathrm{M} .{ }^{80}$ Both AEA and 2-AG also demonstrated antiproliferative effects in the $\mathrm{C} 6$ cell line with $\mathrm{IC}_{50}$ values of 1.6 and $1.8 \mu \mathrm{M}$, respectively. ${ }^{81}$

$\Delta^{9}$-THC shows inhibitory effects in a range of pancreatic cell lines; however, this effect appears to be biphasic, with evidence of proliferation at concentrations under $1 \mu \mathrm{M}$ and inhibition at concentrations above $2 \mu \mathrm{M}$. This biphasic trend was most obvious in the Panc1 and Capan2 cell lines and less obvious in MiaPaCa2 and $\mathrm{BxPc} 3$ cells. ${ }^{82}$ When $\mathrm{MiaPaCa} 2$ cells were implanted subcutaneously into nude mice and left to form tumors, $\Delta^{9}$-THC $(15 \mathrm{mg} / \mathrm{kg} /$ day, 15 days) caused a significant reduction in tumor growth. ${ }^{82}$

Both $\Delta^{9}$-THC and AEA (or the stable equivalent MetAEA) inhibited the growth of lymphoma cell lines, although this effect was related to the serum content of the cell media used. In serum-free media, $\Delta^{9}$-THC showed significant inhibition of growth in EL-4, LSA, and P815 cells at concentrations above $3 \mu \mathrm{M}$. However, with the inclusion of $5 \%$ calf serum in the media, no significant effect was observed until concentrations of $10 \mu \mathrm{M}$ were reached ${ }^{83}$ Herrera et al reported a decrease in the viability of Jurkat cells at concentrations of $1.5 \mu \mathrm{M}$ and above when using heat-inactivated fetal bovine serum, though this study did not assess cell viability in a completely media-free system. ${ }^{84}$ However, several other 
studies have reported a decrease in the cell viability of Jurket cells following exposure to $\Delta^{9}$-THC..$^{83,85-88}$ In mantle-cell lymphoma, two studies reported an effect of AEA or the stable equivalent, Met-AEA, with the effective concentration ranging from 5 to $10 \mu \mathrm{M}$ for each compound. ${ }^{89,90}$

In contrast to the inhibitory effects documented above, the natural cannabinoids have also shown to increase cell proliferation, although normally these results have been documented in studies investigating smoke mixtures that include natural cannabinoid compounds. One study using pure $\Delta^{9}$-THC at concentrations between 0.1 and $0.3 \mu \mathrm{M}$ showed increased proliferation of NCI-H292 lung carcinoma cells. ${ }^{91}$ In the lungs of habitual marijuana smokers, significant increases in the proliferation marker Ki67 were observed along with changes in the expression of the epidermal growth-factor receptor, the human epidermal growthfactor receptor $2 /$ neu receptor, p53, and DNA polyploidy. ${ }^{92}$ In hepatoma cells, $\Delta^{9}$-THC $(2 \mu \mathrm{g} / \mathrm{mL})$ induced the drug metabolizing enzyme cytochrome P450 $1 \mathrm{~A} 1$, which is linked to the development of tobacco-related cancers. ${ }^{93}$ This induction effect was seen with both a marijuana-derived tar mixture and pure extracts of $\Delta^{9}$-THC. No effects on cellular proliferation were reported. ${ }^{93}$ Epidemiological studies around the development of cancer in cannabis smokers have been similarly inconclusive as to whether natural cannabinoids are pro- or anticarcinogenic. ${ }^{94-96}$

\section{Synthetic cannabinoids (WIN-55,2I 2-2, and JWH-133)}

WIN-55,212-2 is a nonselective agonist of $\mathrm{CB}_{1}$ and $\mathrm{CB}_{2}$ that exhibits anticancer effects in prostate, glioblastoma, glioma, breast, lymphoma, and melanoma cell lines. ${ }^{53,79,97,98}$ In the LNCaP prostate cancer cell line, WIN-55,212-2 dosedependently decreased cell viability, with an overall $\mathrm{IC}_{50}$ value of $6 \mu \mathrm{M} .{ }^{53}$ Similar to malignant glioma cells, the levels of both $\mathrm{CB}_{1}$ and $\mathrm{CB}_{2}$ were elevated in this cell line, as well as in DU145, PC3, and CWR22Rv1 lines. ${ }^{53}$ The inhibition of prostate cancer growth can be mediated by both the $\mathrm{CB}_{1}-$ and $\mathrm{CB}_{2}$-receptor isoforms. When WIN-55,212-2 (7.5 $\left.\mu \mathrm{M}\right)$ was coadministered with either SR141716 or SR144528 $(2 \mu \mathrm{M})$, the cell growth recovered. ${ }^{53}$ In a study of cell invasion, WIN-55,212-2 at $1 \mathrm{nM}$ caused a $40 \%$ reduction in the invasion measure of PC 3 cells. ${ }^{97}$ In contrast, in DU-145 cells no reduction was seen until $100 \mathrm{nM}$ (causing a 20\% reduction), and no effect was observed in LNCaP cells. In breast cancer cells (MDA-MB-231 and MDA-MB-468) and an MDA-MB-231 tumor-implant model, WIN-55,212-2 inhibited cell and tumor growth (in vitro $\mathrm{IC}_{50} \leq 10 \mu \mathrm{M}$, in vivo
$5 \mathrm{mg} / \mathrm{kg} /$ day, intratumorally for 4 weeks). ${ }^{54}$ One factor of critical importance in all these studies is the dose of agonist administered. The cannabinoid receptor shows ligandbinding affinity for WIN-55,212-2 within the nanomolar range ( 3 and $16 \mathrm{nM}$ for human $\mathrm{CB}_{1}$ and $\mathrm{CB}_{2}$, respectively). ${ }^{18}$ Therefore, it can be suggested that at doses above $4 \mu \mathrm{M}$, any observed effects may not be cannabinoid receptor-mediated. This warrants further investigation, particularly in the prostate and breast cancer cell lines previously discussed.

WIN-55,212-2 (1.25 $\mu \mathrm{M})$ inhibited cell growth by greater than 50\% in the SF126, U87-MG, U251, U373-MG, and SF-188 glioblastoma cell lines, while in C6 glioma cell lines $15 \mu \mathrm{M}$ was required to generate a similar effect. ${ }^{79,98}$ In vivo, regression of $\mathrm{C} 6$ cell tumors was observed following 8 days of WIN-55,212-2 administration (50 $\mu \mathrm{g} /$ day intratumorally). ${ }^{61}$

In vivo, the growth of melanoma xenografts was decreased in WIN-55,212-2-treated mice. Blázquez et al demonstrated decreased cell viability in the melanomaderived B16 and A375 cell lines and a significant reduction in tumor volume in B16-implanted mice following 8 days of WIN-55,212-2 treatment (50 $\mathrm{g}$ /day, peritumorally). ${ }^{56}$ Similar results were seen in a PDV.C57 implantation model of melanoma, with tumor shrinkage observed following 11 days of WIN-55,212-2 treatment ( $1.5 \mu \mathrm{g}$ /day, peritumorally by continuous-flow pump). ${ }^{99}$

Similarly, WIN-55,212-2 has been shown to have efficacy in mantle-cell lymphoma tumors and cell lines. In Rec-1, JeKo, and JVM-2 cell lines, WIN-55,212-2 induced cell death and cleavage of caspase 3 at doses above $5 \mu \mathrm{M} .{ }^{89,100}$ This effect was blocked by pre-treatment with either a $\mathrm{CB}_{1}$ or $\mathrm{CB}_{2}$ inhibitor (SR141716A or $\left.\mathrm{S} 144528\right) .{ }^{100}$ In tumors derived from mantle-cell lymphoma patient samples, similar cellular toxicity was observed, with $\mathrm{IC}_{50}$ values ranging between 1.47 and $4.81 \mu \mathrm{M}$, depending on the individual patient. ${ }^{60}$ Interestingly, this decrease in cell viability did not correlate with the cleavage of caspase 3 , suggesting that the mechanism of action is not via apoptosis. ${ }^{60}$

JWH-133 is a selective agonist for the $\mathrm{CB}_{2}$ receptor; therefore, it has been investigated as a possible cancer therapeutic that may lack psychoactive side effects. The first study to demonstrate the cytotoxicity of JWH-133 in vitro was conducted in glioma cells. ${ }^{61} \mathrm{CB}_{2}$ is expressed at low levels in microglial cells under normal conditions; however, overexpression is correlated with the development of malignancy. ${ }^{101,102}$ In glioma cells, JWH-133 reduced cell viability by $50 \%$ in vitro, while in vivo studies showed a $71 \%$ decrease in tumor growth after 8 days $\left(\mathrm{Rag}^{-/-}\right.$mice, 
$40 \mu \mathrm{g} /$ day intratumorally). This effect on tumor growth was inhibited by the $\mathrm{CB}_{2}$ antagonist SR144528, but not the $\mathrm{CB}_{1}$ specific antagonist SR141716. ${ }^{61}$ These results are supported by studies in glioma (C6 cells) and astrocytoma xenografts, where the overall vascularization of tumors was reduced by $88 \%$ and $21 \%$ respectively ( $50 \mu \mathrm{g} /$ day intratumorally, 8 or 25 days for gliomas and astrocytes). ${ }^{103}$

In a skin-tumor model, JWH-133 (83 $\mu \mathrm{g}$ /day for 11 days via continuous-flow pump) caused a $60 \%$ decrease in tumor size in PDV.C57 cell xenografts. ${ }^{99}$ In melanoma xenografts, JWH-133 decreased tumor volume by $75 \%$ over an 8 -day period $(50 \mu \mathrm{g} /$ day), with tumors displaying decreased vascularity and increased numbers of apoptotic cells. ${ }^{56}$

In breast cancer cell lines, JWH-133 decreases cell proliferation and induces apoptosis. In the breast MDAMB-231 cell line, a 58\% reduction in growth and migration was observed at $10 \mu \mathrm{M} .{ }^{54} \mathrm{~A}$ similar effect was seen in the MDA-MB-468 breast cancer cell line. These results were confirmed in vivo, with a $46 \%$ reduction in MDA-MB-231implanted tumor growth over an 8 -week period $(5 \mathrm{mg} / \mathrm{kg} /$ day intraperitoneally), an effect that was blocked by the simultaneous administration of SR144528. ${ }^{54}$ In MMTV-neu mice, a model of Erb2-driven metastatic breast cancer, JWH-133 at $50 \mu \mathrm{g} /$ day (peritumorally twice a week for 90 days) exhibited a range of anticancer effects, including decreased tumor size, inhibition of new tumor development, decreased tumor cell proliferation, inhibition of angiogenesis, and decreased lung metastasis. ${ }^{73}$ These results were comparable to findings with the mixed agonist $\Delta^{9}$-THC, suggesting an important role for the $\mathrm{CB}_{2}$ receptor in the $\Delta^{9}$-THC mediated effect.

\section{Overview of potential mechanisms Effects on tumor growth and development}

Cannabinoids affect a range of pathways that regulate cell division and viability; however, the knowledge in this area remains incomplete. For example, it is still difficult to explain the myriad of results around cell survival that have been reported in the literature. This is confounded by a lack of understanding of the possible receptors involved and ongoing doubt over their definitive localization. In addition, the actual mechanisms of cell death remain controversial, with some authors maintaining that autophagy precedes apoptosis and others suggesting that apoptosis is stimulated directly. Current evidence suggests that the type and stage of the cancer is likely to be important, with hormone-dependent cancers possibly reacting differently to cannabinoid exposure than gliomas (the most studied cancer type in terms of cannabinoid action).
Endogenous cannabinoids regulate the de novo synthesis of ceramides, lipid-based components of the cell membrane that perform both structural and signaling functions. It is becoming increasingly obvious that ceramide functions as a physiological signaling molecule, particularly with regard to the control of apoptosis, but also growth arrest, differentiation, cell migration, and adhesion. ${ }^{104}$ As such, the role and regulation of ceramide signaling is attracting increasing attention, and ceramide now has an accepted role in the development of some cancers. ${ }^{105}$ Activation of either $\mathrm{CB}_{1}$ or $\mathrm{CB}_{2}$ in glioma cells is associated with an increase in ceramide levels leading to the activation of the extracellular signal-regulated kinase (ERK) pathway via Raf-1 activation and p38 MAPK activation. ${ }^{14,106}$ Both these pathways ultimately cause apoptosis through caspase activation and/or cell-cycle arrest. ${ }^{14}$ In breast cancer cells, the $\mathrm{CB}_{1}$ antagonist SR141716 inhibited cell proliferation through the effects of ERK1/2 colocalized inside membrane lipid rafts/caveloae. ${ }^{59} \mathrm{Such}$ rafts play a critical role in the growth and metastasis of breast tumors. ${ }^{107,108}$ A final component of the ERK pathway, p53, plays a crucial role in switching between cell-cycle arrest and apoptosis. ${ }^{109} \mathrm{In}$ cultured cortical neurons, $\Delta^{9}$-THC activated $\mathrm{p} 53$ via the $\mathrm{CB}_{1}$ receptor, thereby activating the apoptotic cascade involving B-cell lymphoma (Bcl)-2 and Bcl-2-associated X protein, suggesting that the cannabinoid pathway ultimately causes cellular death via apoptosis. ${ }^{110}$

It is also likely, at least in some cell types, that autophagy precedes the apoptotic cascade. Autophagy has been reported in glioma, pancreatic, breast, and hepatocellular carcinoma cells, with additional reports that WIN-55,212-2 causes autophagy in mantle-cell lymphoma. ${ }^{11,112}$ As yet, there is no evidence for autophagy in rhabdomyosarcoma, leukemia, prostate, or melanoma cell lines. ${ }^{111}$ Autophagy is linked to endoplasmic reticulum stress, and follows similar pathways to the aforementioned ERK-mediated mechanism. The upregulation of ceramide appears to be the likely link between cannabinoid exposure and these endoplasmic reticulum effects. $\mathrm{CB}_{1}$ and $\mathrm{CB}_{2}$ activation induces serine palmitoyltransferase, the rate-limiting step of de novo ceramide synthesis. ${ }^{113}$ Ceramide activates nuclear protein 1 (previously p8) through the action of ER-associated eIF $2 \alpha$ which triggers a signaling cascade through tribbles homologue 3 , AKT, and mammalian target of rapamycin complex 1 to cause autophagy. ${ }^{114}$ This process involves the encapsulation of key organelles in doublemembrane vesicles for breakdown and recycling. There has been debate as to whether this process is cytoprotective or cytotoxic, but it appears it can be both. In the case of cannabinoid treatment, apoptosis through mitochondrial disruption 
is observed. ${ }^{114,115}$ Alternatively, signaling via the putative GPR55 receptor in ovarian and prostate cells activates ERK and AKT signaling pathways, which alters intracellular calcium signaling, thereby affecting cellular proliferation. ${ }^{116}$

In addition to regulation through the ceramide pathway, cannabinoids exhibit a direct effect on cAMP levels through the regulation of adenylate cyclase, downregulation of protein kinase $\mathrm{A}$, and a decrease in gene transcription. ${ }^{14,68,117}$ In hormone-responsive cancer cells, this leads to decreases in the expression of breast cancer-associated antigen 1, prostatespecific antigen, and the androgen receptor in breast and prostate cells, respectively. ${ }^{25,53}$ The downregulation of protein synthesis also results in a decrease in the expression of the high-affinity nerve-growth factor tyrosine-kinase receptor A and the prolactin receptor, thereby decreasing cell sensitivity to key growth promoters. ${ }^{69}$ In addition to cell-level effects through protein kinase $\mathrm{A}$, cannabinoids regulate the action of hormones through the hypothalamic-pituitary-gonadal axis. For example, exposing rats to $\Delta^{9}$-THC $(1 \mathrm{mg} / \mathrm{kg}$, intravenously) or WIN-55,212-2 (0.5 mg/ kg, intravenously) resulted in a decrease in the secretion of luteinizing hormone within 30 minutes. ${ }^{118}$ This effect was blocked by the preadministration of the $\mathrm{CB}_{1}$ antagonist SR141716. ${ }^{118}$ Similar results have been reported for prolactin release, while levels of adrenocorticotropic hormone have been shown to increase following $\Delta^{9}$-THC. ${ }^{119,120}$ Normal anterior pituitary tissue expresses cannabinoid receptors, which indicates that the cannabinoids may be able to exert modulatory actions directly at the level of the pituitary gland. ${ }^{121}$ This further complicates the results that may occur in in vivo investigations of hormone-responsive tumors. However, the decrease in luteinizing hormone may suggest a concomitant decrease in steroid-hormone production that may be protective, especially in breast cancer. ${ }^{122}$

In glioma cells, there is evidence that cannabinoids, specifically cannabidiol, activate apoptosis independently of cannabinoid-receptor binding. The mechanism for this effect is likely to involve the induction of oxidative stress through the generation of reactive oxygen species. This concept is supported by the observation that the antiproliferative effect was not blocked by a $\mathrm{CB}_{2}$ antagonist, but was inhibited by tocopherol, a potent antioxidant. This effect was not observed in noncancerous primary glial cells. ${ }^{123}$

\section{Effects on invasion and metastasis}

Cannabinoids affect a wide range of markers associated with the invasion and metastasis of cancers, including markers of migration, adhesion, invasion, and metastasis itself. ${ }^{124}$ For example, studies on migration have shown that AEA,
2-AG, cannabidiol, HU-210, JWH-133, Met-fluoro-AEA (Met-F-AEA), $\Delta^{9}$-THC, and WIN-55,212-2 all decreased migration, or markers of migration, in a wide range of cell lines. Joseph et al reported that the adrenalin-induced migration of SW480 and MDA-MB-468 cells was inhibited following exposure to AEA or JWH-133 at 40 and $10 \mathrm{nM}$, respectively. ${ }^{125}$ A similar effect was reportedly observed following treatment with HU-210, although detail was not provided. ${ }^{125}$ In T lymphocytes, only JWH-133 (10 nM) was able to reduce stromal cell-derived factor 1-induced migration, with AEA ( $10 \mathrm{nM})$ showing no effect. ${ }^{125}$ These results have been corroborated in cervical cells exposed to 2-AG or WIN-55,212-2, with both compounds reducing scratch closure in monolayers of SW756 cells. ${ }^{126}$ Cannabidiol $(\geq 3 \mu \mathrm{M})$ inhibited the migration of U87 glioma cells in a Boyden chamber assay, but interestingly this effect was not blocked by the cannabinoid receptor antagonists SR141716 $\left(\mathrm{CB}_{1}\right)$ or SR144528 $\left(\mathrm{CB}_{2}\right){ }^{127}$ This suggests that some, if not all, the migration effects observed in cell systems may not be mediated by the cannabinoid receptor.

The adhesion of cells within the extracellular matrix is an important component of maintaining correct multicellular structure, with dysfunction of this process associated with metastasis. In a model of metastatic spreading using MDA-MB-231 cells, Met-F-AEA ( $0.5 \mathrm{mg} / \mathrm{kg}$ every 72 hours for 21 days) significantly reduced the number and size of metastatic nodes, an effect antagonized by SR $141716 .{ }^{128}$ The authors were able to demonstrate that the effect on metastasis was linked to the phosphorylation of two tyrosine-kinase proteins involved in migration and adhesion: focal adhesion kinase (FAK) and Src. ${ }^{128}$ This contradicts previous results in neuroblastoma cells, where HU-210 at $10 \mathrm{nM}$ caused phosphorylation of the FAK-related nonkinase but not FAK itself. ${ }^{129}$ However, WIN-55,212-2 $(20 \mu \mathrm{M})$ also modulated a range of adhesion proteins, including intercellular adhesion molecule 1, IL-1, vascular cell-adhesion protein 1, and IL-8. ${ }^{130}$ The authors conclude that this inhibition of the IL-1 pathway is mediated by effects of WIN-55,212-2 on nuclear factor $\mathrm{\kappa B}$ transactivation. This inhibition is likely to mediate a range of downstream effects, including anti-inflammatory and anticancerous actions. ${ }^{130}$

Tissue inhibitors of matrix metalloproteinases (TIMPs) may be a key mechanism by which cannabinoids inhibit tissue invasion. Decreased TIMP expression is highly correlated with cancer invasiveness, and the expression of TIMP-1 is a potent suppressor of tumor growth and angiogenesis. ${ }^{131,132}$ However, the effect of cannabinoids on TIMP expression levels is controversial. Several studies have documented 
an increase in TIMP-1 levels following cannabinoid administration. In lung and cervical cell lines (A549 and HeLa, C33A, respectively), $\Delta^{9}$-THC at $0.01 \mu \mathrm{M}$ increased the expression of TIMP-1, which correlated with a decrease in cell invasion. ${ }^{133}$ This effect was blocked by the preadministration of the specific inverse agonists AM-251 ( $\left.\mathrm{CB}_{1}\right)$ or AM-630 $\left(\mathrm{CB}_{2}\right) .{ }^{133}$ However, $\Delta^{9}$-THC decreased TIMP-1 expression in C6.9 and C6.4 glioma cell lines, a result that was confirmed in biopsies from patients with recurrent glioblastoma multiforme tumors undergoing a clinical trial of THC efficacy. ${ }^{134} \mathrm{JWH}-$ 133 also downregulated TIMP-1 expression in glioma cells. ${ }^{134}$ This suggests that the effects of cannabinoids on invasion may prove to be cancer- and cannabinoid-specific.

In terms of migration, cannabidiol, Met-F-AEA, $\Delta^{9}$-THC, and WIN-55,212-2 have all proven to have direct effects on migration markers. In breast cancer cells, cannabidiol decreased lung metastasis of MDA-MB-231 cells, ${ }^{135}$ while Met-F-AEA inhibited the migration of this cell line on type IV collagen. ${ }^{128}$ This effect was also seen in the TSA-E1 murine breast cancer cell line and was antagonized by the administration of SR $141716 .{ }^{128}$ Similarly, $\Delta^{9}$-THC (1-20 $\left.\mu \mathrm{M}\right)$ inhibited the epidermal growth factor-induced growth, chemotaxis, and chemoinvasion of the lung cancer cell lines A549 and SW1573. ${ }^{136}$ Finally, WIN-55,212-2 (50 $\mu \mathrm{g} /$ day, daily for 8 days) reduced the metastasis of B16 melanoma cells to the lung and liver in a nude mouse implantation model. ${ }^{56}$

All these results suggest that overall the cannabinoids affect multiple cellular signaling pathways, which means they have the potential to decrease cancer development, growth, and metastasis. However, there are likely to be both cancer- and cannabinoid-specific elements to these effects. The final role of the cannabinoid receptors $\left(\mathrm{CB}_{1}\right.$ and $\left.\mathrm{CB}_{2}\right)$ versus novel receptors (eg, GPR55) is also likely to be of ongoing importance.

\section{Effects on angiogenesis}

Angiogenesis is critical for tumor development, and many anticancer agents are selected for their antiangiogenic properties. In vivo models show tumors from cannabinoidtreated animals have a decreased number of sprouting blood vessels, reduced vascular networks, and small, undifferentiated intratumoral blood vessels. ${ }^{103,137,138}$ Cannabinoids may produce a dual attack on the development of tumor blood vessels, through the inhibition of proangiogenic regulators, such as vascular endothelial growth factor (VEGF), and through a direct effect on endothelial cells. ${ }^{103}$

A number of experiments have determined that the levels of the major vascularization factors, including VEGF, are downregulated following administration of $\Delta^{9}$-THC, Met-F-AEA, WIN-55,212-2, and JWH-133. ${ }^{103} \Delta^{9}$-THC decreased VEGF levels in lung cancer cell lines (A549 and SW1573), and this effect correlated with a decrease in vascularization of A549 xenoplantation tumors in severe combined immunodeficient mice. ${ }^{136}$ Met-F-AEA decreased the production of VEGF and the expression of its receptor, VEGFR-1, in K-ras-transformed thyroid cells. ${ }^{138}$ WIN55,212-2 and JWH-133 both showed inhibitory effects on VEGF and related markers of angiogenesis in skin carcinoma tumors (implanted PDV.C57 cells). ${ }^{99}$ JWH-133 downregulated VEGF in subcutaneously implanted glioma cells, and caused a concomitant decrease in the associated compounds connective tissue growth factor, heme oxygenase 1, Id-3, midkine, and Tie-1. ${ }^{139}$ Overall, cannabinoids appear to have consistent effects on the vascularization pathway, causing a decrease in tumor vascularization in in vivo models.

The endothelial cell lines human umbilical vein endothelial cells (HUVEC) and ECV304 showed direct susceptibility to WIN-55,212-2, with exposure to concentrations above $25 \mathrm{nM}$ inducing cell death. ${ }^{103}$ This effect was repeatable on exposure to other cannabinoids, including HU-210 (25 nM), $\Delta^{9}$-THC $(1 \mu \mathrm{M})$, or JWH-133 $(25 \mathrm{nM}) .{ }^{103}$ Similarly, the administration of synthetic cannabinoid analogues (LYR-7 or LYR-8) both decreased HUVEC viability at concentrations of $5 \mu \mathrm{M}$ and above. ${ }^{140}$ However, this effect was not blocked by the preincubation of cells with the specific inhibitors AM281 $\left(\mathrm{CB}_{1}\right)$ or AM630 $\left(\mathrm{CB}_{2}\right) \cdot{ }^{140}$ Therefore, the cannabinoids show significant potential as antiangiogenic agents, and this may prove key to their success as a clinical therapy, but the role of the cannabinoid receptors in this response is still to be fully elucidated.

\section{The future of cannabinoid compounds in cancer treatment}

Overall, the cannabinoids may show future promise in the treatment of cancer, but there are many significant hurdles to be overcome. There is much still to be learned about the action of the cannabinoids and the endocannabinoid system. The current disagreements in the literature suggest gaps remain in the knowledge base around the normal signaling pathways used by endocannabinoids, the physiological systems that are involved, and the range of effects that these compounds cause. Future research will help clarify the actions of the cannabinoids, and particularly the endocannabinoid signaling pathway, which will be critical in the ongoing development of these compounds. 
It is a distinct possibility that the cannabinoids may have a place in the future treatment of cancer. Several reports have shown that the synthetic cannabinoids in particular have the potential to show sufficient specificity and efficacy to be precursors to clinical treatments. However, at this point in time, the results from studies are lacking sufficient depth of understanding to allow this transition to occur. The contradictory nature of reports around the efficacy of compounds highlights our lack of detailed understanding of mechanisms of action. The resolution of the conflicting evidence around cannabinoid action will continue to be a research priority in the near future, and it is expected that developing a more robust understanding of the mechanisms of action underlying cannabinoid action will facilitate the acceptance of cannabinoid use in a clinical setting.

\section{Disclosure}

The authors declare they have no conflict of interest, financial or otherwise, regarding this work.

\section{References}

1. Alexander A, Smith PF, Rosengren RJ. Cannabinoids in the treatment of cancer. Cancer Lett. 2009;285(1):6-12.

2. Cameron L, Williams J. Cannabis, alcohol and cigarettes: substitutes or complements? Econ Rec. 2001;77(236):19-34.

3. Gaoni Y, Mechoulam R. Isolation, structure, and partial synthesis of an active constituent of hashish. J Am Chem Soc. 1964;86(8):1646-1647.

4. Devane W, Hanus L, Breuer A, et al. Isolation and structure of a brain constituent that binds to the cannabinoid receptor. Science. 1992;258(5090):1946-1949.

5. Console-Bram L, Marcu J, Abood ME. Cannabinoid receptors: nomenclature and pharmacological principles. Prog Neuropsychopharmacology Biol Psychiatry. 2012;38(1):4-15.

6. Piomelli D. Arachidonic acid in cell signaling. Curr Opin Cell Biol. 1993;5(2):274-280.

7. Mechoulam R, Fride E, Di Marzo V. Endocannabinoids. Eur $J$ Pharmacol. 1998;359(1):1-18.

8. Maccarrone M, Finazzi-Agrò A. Endocannabinoids and their actions. Vitam Horm. 2002;65:225-255.

9. Devane WA, Dysarz FA, Johnson MR, Melvin LS, Howlett AC. Determination and characterization of a cannabinoid receptor in rat brain. Mol Pharmacol. 1988;34(5):605-613.

10. Matsuda LA, Lolait SJ, Brownstein MJ, Young AC, Bonner TI. Structure of a cannabinoid receptor and functional expression of the cloned cDNA. Nature. 1990;346(6284):561-564.

11. Munro S, Thomas KL, Abu-Shaar M. Molecular characterization of a peripheral receptor for cannabinoids. Nature. 1993;365(6441):61-65.

12. Pertwee RG. Cannabinoid pharmacology: the first 66 years. $\mathrm{Br} \mathrm{J}$ Pharmacol. 2006;147 Suppl 1:S163-S171.

13. Guzmán M. Cannabinoids: potential anticancer agents. Nat Rev Cancer. 2003;3(10):745-755.

14. Sarfaraz S, Adhami VM, Syed DN, Afaq F, Mukhtar H. Cannabinoids for cancer treatment: progress and promise. Cancer Res. 2008;68(2): 339-342.

15. Lange JH, Kruse CG. Recent advances in CB1 cannabinoid receptor antagonists. Curr Opin Drug Discov Devel. 2004;7(4):498-506.

16. Bergman J, Delatte MS, Paronis CA, Vemuri K, Thakur GA, Makriyannis A. Some effects of CB1 antagonists with inverse agonist and neutral biochemical properties. Physiol Behav. 2008;93(4-5):666-670.
17. Ross RA, Brockie HC, Stevenson LA, et al. Agonist-inverse agonist characterization at $\mathrm{CB} 1$ and $\mathrm{CB} 2$ cannabinoid receptors of L759633, L759656 and AM630. Br J Pharmacol. 1999;126(3):665-672.

18. McPartland JM, Glass M, Pertwee RG. Meta-analysis of cannabinoid ligand binding affinity and receptor distribution: interspecies differences. Br J Pharmacol. 2007;152(5):583-593.

19. Brown AJ. Novel cannabinoid receptors. Br J Pharmacol. 2007;152(5): 567-575.

20. Pertwee RG, Howlett AC, Abood ME, et al. International Union of Basic and Clinical Pharmacology. LXXIX. Cannabinoid receptors and their ligands: beyond CB1 and CB2. Pharmacol Rev. 2010;62(4): 588-631.

21. Godlewski G, Kunos G. Overview of nonclassical cannabinoid receptors. In: Abood ME, Sorensen RG, Stella N, editors. Endocannabinoids: Actions at Non-CB1/CB2 Cannabinoid Receptors. New York: Springer; 2013:3-27.

22. Marzo V, Petrocellis L. Temperature-sensitive transient receptor potential channels as ionotropic cannabinoid receptors. In: Abood ME, Sorensen RG, Stella N, editors. Endocannabinoids: Actions at Non-CB1/ CB2 Cannabinoid Receptors. New York: Springer; 2013:175-197.

23. Oddi S, Fezza F, Pasquariello N, et al. Evidence for the intracellular accumulation of anandamide in adiposomes. Cell Mol Life Sci. 2008;65(5):840-850.

24. Rodríguez De Fonseca F, Del Arco I, Bermudez-Silva FJ, Bilbao A, Cippitelli A, Navarro M. The endocannabinoid system: physiology and pharmacology. Alcohol Alcohol. 2005;40(1):2-14.

25. De Petrocellis L, Melck D, Palmisano A, et al. The endogenous cannabinoid anandamide inhibits human breast cancer cell proliferation. Proc Natl Acad Sci U SA. 1998;95(14):8375-8380.

26. Fonseca BM, Costa MA, Almada M, Correia-da-Silva G, Teixeira NA. Endogenous cannabinoids revisited: a biochemistry perspective. Prostaglandins Other Lipid Mediat. 2013;102-103:13-30.

27. Ueda N, Puffenbarger RA, Yamamoto S, Deutsch DG. The fatty acid amide hydrolase (FAAH). Chem Phys Lipids. 2000;108(1-2):107-121.

28. Gulyas AI, Cravatt BF, Bracey MH, et al. Segregation of two endocannabinoid-hydrolyzing enzymes into pre- and postsynaptic compartments in the rat hippocampus, cerebellum and amygdala. Eur J Neurosci. 2004;20(2):441-458.

29. Woo AY, Wang TB, Zeng X, et al. Stereochemistry of an agonist determines coupling preference of $\beta 2$-adrenoceptor to different G proteins in cardiomyocytes. Mol Pharmacol. 2009;75(1):158-165.

30. Glass M, Northup JK. Agonist selective regulation of G proteins by cannabinoid CB1 and CB2 receptors. Mol Pharmacol. 1999;56(6): $1362-1369$.

31. Turu G, Hunyady L. Signal transduction of the CB1 cannabinoid receptor. J Mol Endocrinol. 2010;44(2):75-85.

32. Howlett AC, Breivogel CS, Childers SR, Deadwyler SA, Hampson RE, Porrino LJ. Cannabinoid physiology and pharmacology: 30 years of progress. Neuropharmacology. 2004;47 Suppl 1:345-358.

33. Abood ME, Martin BR. Neurobiology of marijuana abuse. Trends Pharmacol Sci. 1992;13(5):201-206.

34. Walker JM, Huang SM. Cannabinoid analgesia. Pharmacol Ther. 2002;95(2):127-135.

35. Freund TF, Katona I, Piomelli D. Role of endogenous cannabinoids in synaptic signaling. Physiol Rev. 2003;83(3):1017-1066.

36. Breivogel CS, Childers SR. The functional neuroanatomy of brain cannabinoid receptors. Neurobiol Dis. 1998;5(6 Pt B):417-431.

37. Patel S, Hillard CJ. Cannabinoid CB1 receptor agonists produce cerebellar dysfunction in mice. J Pharmacol Exp Ther. 2001;297(2): 629-637.

38. Pertwee RG, Wickens AP. Enhancement by chlordiazepoxide of catalepsy induced in rats by intravenous or intrapallidal injections of enantiomeric cannabinoids. Neuropharmacology. 1991;30(3): 237-244.

39. Monory K, Blaudzun H, Massa F, et al. Genetic dissection of behavioural and autonomic effects of $\Delta 9$-tetrahydrocannabinol in mice. PLoS Biol. 2007;5(10):e269. 
40. Turcotte D, Le Dorze JA, Esfahani F, Frost E, Gomori A, Namaka M. Examining the roles of cannabinoids in pain and other therapeutic indications: a review. Expert Opin Pharmacother. 2010;11(1):17-31.

41. Drew LJ, Harris J, Millns PJ, Kendall DA, Chapman V. Activation of spinal cannabinoid 1 receptors inhibits $\mathrm{C}$-fibre driven hyperexcitable neuronal responses and increases [35S]GTP $\gamma \mathrm{S}$ binding in the dorsal horn of the spinal cord of noninflamed and inflamed rats. Eur J Neurosci. 2000;12(6):2079-2086.

42. Hohmann AG, Briley EM, Herkenham M. Pre- and postsynaptic distribution of cannabinoid and mu opioid receptors in rat spinal cord. Brain Res. 1999;822(1-2):17-25.

43. Klein TW, Newton C, Larsen K, et al. The cannabinoid system and immune modulation. J Leukoc Biol. 2003;74(4):486-496.

44. Ashton JC. The use of knockout mice to test the specificity of antibodies for cannabinoid receptors. Hippocampus. 2012;22(3):643-644.

45. Borner C, Hollt V, Kraus J. Activation of human T cells induces upregulation of cannabinoid receptor type 1 transcription. Neuroimmunomodulation. 2007;14(6):281-286.

46. Galiègue S, Mary S, Marchand J, et al. Expression of central and peripheral cannabinoid receptors in human immune tissues and leukocyte subpopulations. Eur J Biochem. 1995;232(1):54-61.

47. Klein TW, Lane B, Newton CA, Friedman H. The cannabinoid system and cytokine network. Proc Soc Exp Biol Med. 2000;225(1):1-8.

48. Tanasescu R, Constantinescu CS. Cannabinoids and the immune system: an overview. Immunobiology. 2010;215(8):588-597.

49. Pisanti S, Malfitano AM, Grimaldi C, et al. Use of cannabinoid receptor agonists in cancer therapy as palliative and curative agents. Best Pract Res Clin Endocrinol Metab. 2009;23(1):117-131.

50. Bowles DW, O'Bryant CL, Camidge DR, Jimeno A. The intersection between cannabis and cancer in the United States. Crit Rev Oncol Hematol. 2012;83(1):1-10.

51. Todaro B. Cannabinoids in the treatment of chemotherapy-induced nausea and vomiting. J Natl Comp Canc Netw. 2012;10(4):487-492.

52. Munson AE, Harris LS, Friedman MA, Dewey WL, Carchman RA Antineoplastic activity of cannabinoids. J Natl Cancer Inst. 1975;55(3): 597-602.

53. Sarfaraz S, Afaq F, Adhami VM, Mukhtar H. Cannabinoid receptor as a novel target for the treatment of prostate cancer. Cancer Res. 2005;65(5):1635-1641.

54. Qamri Z, Preet A, Nasser MW, et al. Synthetic cannabinoid receptor agonists inhibit tumor growth and metastasis of breast cancer. Mol Cancer Ther. 2009;8(11):3117-3129.

55. Bouaboula M, Rinaldi M, Carayon P, et al. Cannabinoid-receptor expression in human leukocytes. Eur J Biochem. 1993;214(1): $173-180$

56. Blázquez C, Carracedo A, Barrado L, et al. Cannabinoid receptors as novel targets for the treatment of melanoma. FASEB J. 2006;20(14): 2633-2635.

57. Wang D, Wang H, Ning W, Backlund MG, Dey SK, DuBois RN. Loss of cannabinoid receptor 1 accelerates intestinal tumor growth. Cancer Res. 2008;68(15):6468-6476.

58. Xu X, Liu Y, Huang S, et al. Overexpression of cannabinoid receptors $\mathrm{CB} 1$ and CB2 correlates with improved prognosis of patients with hepatocellular carcinoma. Cancer Genet Cytogenet. 2006;171(1):31-38.

59. Sarnataro D, Pisanti S, Santoro A, et al. The cannabinoid CB1 receptor antagonist rimonabant (SR141716) inhibits human breast cancer cell proliferation through a lipid raft-mediated mechanism. Mol Pharmacol. 2006;70(4):1298-1306.

60. Wasik AM, Christensson B, Sander B. The role of cannabinoid receptors and the endocannabinoid system in mantle cell lymphoma and other non-Hodgkin lymphomas. Semin Cancer Biol. 2011;21(5):313-321.

61. Sánchez C, de Ceballos ML, Gomez del Pulgar T, et al. Inhibition of glioma growth in vivo by selective activation of the CB2 cannabinoid receptor. Cancer Res. 2001;61(15):5784-5789.

62. McKallip RJ, Nagarkatti M, Nagarkatti PS. $\Delta$-9-Tetrahydrocannabinol enhances breast cancer growth and metastasis by suppression of the antitumor immune response. J Immunol. 2005;174(6):3281-3289.
63. Rinaldi-Carmona M, Le Duigou A, Oustric D, et al. Modulation of CB1 cannabinoid receptor functions after a long-term exposure to agonist or inverse agonist in the Chinese hamster ovary cell expression system. J Pharmacol Exp Ther. 1998;287(3):1038-1047.

64. Leterrier C, Bonnard D, Carrel D, Rossier J, Lenkei Z. Constitutive endocytic cycle of the CB1 cannabinoid receptor. J Biol Chem. 2004;279(34):36013-36021.

65. Castaneda J, Harui A, Kiertscher S, Roth J, Roth M. Differential expression of intracellular and extracellular CB2 cannabinoid receptor protein by human peripheral blood leukocytes. J Neuroimmune Pharmacol. 2013;8(1):323-332.

66. Bifulco M, Laezza C, Pisanti S, Gazzerro P. Cannabinoids and cancer: pros and cons of an antitumour strategy. Br J Pharmacol. 2006;148(2): 123-135.

67. Massi P, Solinas M, Cinquina V, Parolaro D. Cannabidiol as potential anticancer drug. Br J Clin Pharmacol. 2013;75(2):303-312.

68. Guindon J, Hohmann AG. The endocannabinoid system and cancer: therapeutic implication. Br J Pharmacol. 2011;163(7):1447-1463.

69. Caffarel MM, Andradas C, Pérez-Gómez E, Guzmán M, Sánchez C. Cannabinoids: a new hope for breast cancer therapy? Cancer Treat Rev. 2012;38(7):911-918.

70. Takeda S, Yamamoto I, Watanabe K. Modulation of $\Delta 9$-tetrahydrocannabinol-induced MCF-7 breast cancer cell growth by cyclooxygenase and aromatase. Toxicology. 2009;259(1-2):25-32.

71. McAllister SD, Christian RT, Horowitz MP, Garcia A, Desprez PY. Cannabidiol as a novel inhibitor of Id-1 gene expression in aggressive breast cancer cells. Mol Cancer Ther. 2007;6(11):2921-2927.

72. Von Bueren AO, Schlumpf M, Lichtensteiger W. Delta(9)tetrahydrocannabinol inhibits $17 \beta$-estradiol-induced proliferation and fails to activate androgen and estrogen receptors in MCF7 human breast cancer cells. Anticancer Res. 2008;28(1A):85-89.

73. Caffarel MM, Andradas C, Mira E, et al. Cannabinoids reduce ErbB2driven breast cancer progression through Akt inhibition. Mol Cancer. 2010;9:196.

74. Sánchez MG, Ruiz-Llorente L, Sánchez AM, Díaz-Laviada I. Activation of phosphoinositide 3-kinase/PKB pathway by $\mathrm{CB} 1$ and CB2 cannabinoid receptors expressed in prostate PC-3 cells. Involvement in Raf-1 stimulation and NGF induction. Cell Signal. 2003;15(9): 851-859.

75. Sánchez MG, Sánchez AM, Ruiz-Llorente L, Díaz-Laviada I. Enhancement of androgen receptor expression induced by (R)methanandamide in prostate LNCaP cells. FEBS Lett. 2003;555(3): 561-566.

76. Mimeault M, Pommery N, Wattez N, Bailly C, Hénichart JP. Antiproliferative and apoptotic effects of anandamide in human prostatic cancer cell lines: implication of epidermal growth factor receptor downregulation and ceramide production. Prostate. 2003;56(1):1-12.

77. Nithipatikom K, Isbell MA, Endsley MP, Woodliff JE, Campbell WB. Anti-proliferative effect of a putative endocannabinoid, 2-arachidonylglyceryl ether in prostate carcinoma cells. Prostaglandins Other Lipid Mediat. 2011;94(1-2):34-43.

78. Jacobsson SOP, Rongård E, Stridh M, Tiger G, Fowler CJ. Serumdependent effects of tamoxifen and cannabinoids upon C6 glioma cell viability. Biochem Pharmacol. 2000;60(12):1807-1813.

79. McAllister S, Chan C, Taft R, et al. Cannabinoids selectively inhibit proliferation and induce death of cultured human glioblastoma multiforme cells. J Neurooncol. 2005;74(1):31-40.

80. Massi P, Vaccani A, Ceruti S, Colombo A, Abbracchio MP, Parolaro D. Antitumor effects of cannabidiol, a nonpsychoactive cannabinoid, on human glioma cell lines. J Pharmacol Exp Ther. 2004;308(3):838-845.

81. Jacobsson SOP, Wallin T, Fowler CJ. Inhibition of rat C6 glioma cell proliferation by endogenous and synthetic cannabinoids. Relative involvement of cannabinoid and vanilloid receptors. J Pharmacol Exp Ther. 2001;299(3):951-959.

82. Carracedo A, Gironella M, Lorente M, et al. Cannabinoids induce apoptosis of pancreatic tumor cells via endoplasmic reticulum stressrelated genes. Cancer Res. 2006;66(13):6748-6755. 
83. McKallip RJ, Lombard C, Fisher M, et al. Targeting CB2 cannabinoid receptors as a novel therapy to treat malignant lymphoblastic disease. Blood. 2002;100(2):627-634.

84. Herrera B, Carracedo A, Diez-Zaera M, Gómez del Pulgar T, Guzmán M, Velasco G. The CB2 cannabinoid receptor signals apoptosis via ceramide-dependent activation of the mitochondrial intrinsic pathway. Exp Cell Res. 2006;312(11):2121-2131.

85. Jia W, Hegde VL, Singh NP, et al. Delta9-tetrahydrocannabinolinduced apoptosis in Jurkat leukemia T cells is regulated by translocation of Bad to mitochondria. Mol Cancer Res. 2006;4(8):549-562.

86. McKallip RJ, Jia W, Schlomer J, Warren JW, Nagarkatti PS, Nagarkatti M. Cannabidiol-induced apoptosis in human leukemia cells: a novel role of cannabidiol in the regulation of p22phox and Nox4 expression. Mol Pharmacol. 2006;70(3):897-908.

87. Lombard C, Nagarkatti M, Nagarkatti PS. Targeting cannabinoid receptors to treat leukemia: role of cross-talk between extrinsic and intrinsic pathways in delta9-tetrahydrocannabinol (THC)-induced apoptosis of Jurkat cells. Leuk Res. 2005;29(8):915-922.

88. Herrera B, Carracedo A, Diez-Zaera M, Guzmán M, Velasco G. p38 MAPK is involved in CB2 receptor induced apoptosis of human leukaemia cells. FEBS Lett. 2005;579(22):5084-5088.

89. Flygare J, Gustafsson K, Kimby E, Christensson B, Sander B. Cannabinoid receptor ligands mediate growth inhibition and cell death in mantle cell lymphoma. FEBS Lett. 2005;579(30):6885-6889.

90. Gustafsson K, Wang X, Severa D, et al. Expression of cannabinoid receptors type 1 and type 2 in non-Hodgkin lymphoma: growth inhibition by receptor activation. Int J Cancer. 2008;123(5):1025-1033.

91. Hart S, Fischer OM, Ullrich A. Cannabinoids induce cancer cell proliferation via tumor necrosis factor alpha-converting enzyme (TACE/ADAM17)-mediated transactivation of the epidermal growth factor receptor. Cancer Res. 2004;64(6):1943-1950.

92. Barsky SH, Roth MD, Kleerup EC, Simmons M, Tashkin DP. Histopathologic and molecular alterations in bronchial epithelium in habitual smokers of marijuana, cocaine, and/or tobacco. J Natl Cancer Inst. 1998;90(16):1198-1205.

93. Roth MD, Marques-Magallanes JA, Yuan M, Sun W, Tashkin DP, Hankinson O. Induction and regulation of the carcinogen-metabolizing enzyme CYP1A1 by marijuana smoke and 9-tetrahydrocannabinol. Am J Respir Cell Mol Biol. 2001;24(3):339-344.

94. Marcus DM, Jani AB, Rossi PJ. Population-based case-control study of recreational drug use and testis cancer risk confirms an association between marijuana use and nonseminoma risk. Cancer. 2013; 119(6): 1284

95. D'Souza G, Palefsky JM, Zhong Y, et al. Marijuana use is not associated with cervical human papillomavirus natural history or cervical neoplasia in HIV-seropositive or HIV-seronegative women. Cancer Epidemiol Biomarkers Prev. 2010;19(3):869-872.

96. Liang C, McClean MD, Marsit C, et al. A population-based casecontrol study of marijuana use and head and neck squamous cell carcinoma. Cancer Prev Res (Phila). 2009;2(8):759-768.

97. Nithipatikom K, Endsley MP, Isbell MA, et al. 2-Arachidonoylglycerol: a novel inhibitor of androgen-independent prostate cancer cell invasion. Cancer Res. 2004;64(24):8826-8830.

98. Ellert-Miklaszewska A, Kaminska B, Konarska L. Cannabinoids downregulate $\mathrm{PI} 3 \mathrm{~K} / \mathrm{Akt}$ and Erk signalling pathways and activate proapoptotic function of Bad protein. Cell Signal. 2005;17(1):25-37.

99. Casanova ML, Blázquez C, Martínez-Palacio J, et al. Inhibition of skin tumor growth and angiogenesis in vivo by activation of cannabinoid receptors. J Clin Invest. 2003;111(1):43-50.

100. Gustafsson K, Christensson B, Sander B, Flygare J. Cannabinoid receptor-mediated apoptosis induced by $R(+)$-methanandamide and Win55,212-2 is associated with ceramide accumulation and p38 activation in mantle cell lymphoma. Mol Pharmacol. 2006;70(5): 1612-1620.

101. Fernández-Ruiz J, Romero J, Velasco G, Tolón RM, Ramos JA, Guzmán M. Cannabinoid CB2 receptor: a new target for controlling neural cell survival? Trends Pharmacol Sci. 2007;28(1):39-45.
102. Ellert-Miklaszewska A, Grajkowska W, Gabrusiewicz K, Kaminska B, Konarska L. Distinctive pattern of cannabinoid receptor type II (CB2) expression in adult and pediatric brain tumors. Brain Res. 2007; 1137(1):161-169.

103. Blázquez C, Casanova ML, Planas A, et al. Inhibition of tumor angiogenesis by cannabinoids. FASEB J. 2003;17(3):529-531.

104. Hannun YA, Obeid LM. Principles of bioactive lipid signalling: lessons from sphingolipids. Nat Rev Mol Cell Biol. 2008;9(2): $139-150$.

105. Morad SAF, Cabot MC. Ceramide-orchestrated signalling in cancer cells. Nat Rev Cancer. 2013;13(1):51-65.

106. Galve-Roperh I, Sánchez C, Cortés ML, Gómez del Pulgar T, Izquierdo M, Guzmán M. Anti-tumoral action of cannabinoids: Involvement of sustained ceramide accumulation and extracellular signal-regulated kinase activation. Nat Med. 2000;6(3): 313-319.

107. Williams TM, Medina F, Badano I, et al. Caveolin-1 gene disruption promotes mammary tumorigenesis and dramatically enhances lung metastasis in vivo: role of Cav-1 in cell invasiveness and matrix metalloproteinase (MMP-2/9) secretion. J Biol Chem. 2004;279(49): 51630-51646.

108. Sloan EK, Stanley KL, Anderson RL. Caveolin-1 inhibits breast cancer growth and metastasis. Oncogene. 2004;23(47):7893-7897.

109. Vousden KH, Lu X. Live or let die: the cell's response to p53. Nat Rev Cancer. 2002;2(8):594-604.

110. Downer EJ, Gowran A, Murphy AC, Campbell VA. The tumour suppressor protein, p53, is involved in the activation of the apoptotic cascade by $\Delta 9$-tetrahydrocannabinol in cultured cortical neurons. Eur J Pharmacol. 2007;564(1-3):57-65.

111. Velasco G, Sánchez C, Guzmán M. Towards the use of cannabinoids as antitumour agents. Nat Rev Cancer. 2012;12(6):436-444.

112. Shrivastava A, Kuzontkoski PM, Groopman JE, Prasad A. Cannabidiol induces programmed cell death in breast cancer cells by coordinating the cross-talk between apoptosis and autophagy. Mol Cancer Ther. 2011;10(7):1161-1172.

113. Gómez del Pulgar T, Velasco G, Sánchez C, Haro A, Guzmán M. De novo-synthesized ceramide is involved in cannabinoid-induced apoptosis. Biochem J. 2002;363(Pt 1):183-188.

114. Salazar M, Lorente M, García-Taboada E, et al. The pseudokinase tribbles homologue-3 plays a crucial role in cannabinoid anticancer action. Biochim Biophys Acta. Epub April 6, 2013.

115. Salazar M, Carracedo A, Salanueva IJ, et al. TRB3 links ER stress to autophagy in cannabinoid antitumoral action. Autophagy. 2009;5(7):1048-1049.

116. Pineiro R, Maffucci T, Falasca M. The putative cannabinoid receptor GPR55 defines a novel autocrine loop in cancer cell proliferation. Oncogene. 2011;30(2):142-152.

117. Bifulco M, Malfitano AM, Pisanti S, Laezza C. Endocannabinoids in endocrine and related tumours. Endocr Relat Cancer. 2008;15(2): 391-408

118. Murphy LL, Muñoz RM, Adrian BA, et al. Function of cannabinoid receptors in the neuroendocrine regulation of hormone secretion. Neurobiol Dis. 1998;5(6):432-446.

119. de Miguel R, Romero J, Muñoz RM, et al. Effects of cannabinoids on prolactin and gonadotrophin secretion: involvement of changes in hypothalamic $\gamma$-aminobutyric acid (GABA) inputs. Biochem Pharmacol. 1998;56(10):1331-1338.

120. Dewey WL, Peng TC, Harris LS. The effect of 1-trans- $\Delta$ 9tetrahydrocannabinol on the hypothalamo-hypophyseal-adrenal axis of rats. Eur J Pharmacol. 1970;12(3):382-384.

121. Pagotto U, Marsicano G, Fezza F, et al. Normal human pituitary gland and pituitary adenomas express cannabinoid receptor type 1 and synthesize endogenous cannabinoids: first evidence for a direct role of cannabinoids on hormone modulation at the human pituitary level. J Clin Endocrinol Metab. 2001;86(6):2687-2696.

122. Bernstein L, Ross RK. Endogenous hormones and breast cancer risk. Epidemiol Rev. 1993;15(1):48-65. 
123. Massi P, Vaccani A, Bianchessi S, Costa B, Macchi P, Parolaro D. The non-psychoactive cannabidiol triggers caspase activation and oxidative stress in human glioma cells. Cell Mol Life Sci. 2006;63(17): 2057-2066.

124. Hermanson D, Marnett L. Cannabinoids, endocannabinoids, and cancer. Cancer Metastasis Rev. 2011;30(3-4):599-612.

125. Joseph J, Niggemann B, Zaenker K, Entschladen F. Anandamide is an endogenous inhibitor for the migration of tumor cells and T lymphocytes. Cancer Immunol Immunother. 2004;53(8):723-728.

126. Rudolph MI, Boza Y, Yefi R, et al. The influence of mast cell mediators on migration of SW756 cervical carcinoma cells. J Pharmacol Sci. 2008;106(2):208-218.

127. Vaccani A, Massi P, Colombo A, Rubino T, Parolaro D. Cannabidiol inhibits human glioma cell migration through a cannabinoid receptorindependent mechanism. Br J Pharmacol. 2005;144(8):1032-1036.

128. Grimaldi C, Pisanti S, Laezza C, et al. Anandamide inhibits adhesion and migration of breast cancer cells. Exp Cell Res. 2006;312(4): 363-373.

129. Zhou D, Song ZH. CB1 cannabinoid receptor-mediated tyrosine phosphorylation of focal adhesion kinase-related non-kinase. FEBS Lett. 2002;525(1-3):164-168.

130. Curran NM, Griffin BD, O’Toole D, Brady KJ, Fitzgerald SN, Moynagh PN. The synthetic cannabinoid R(+)WIN 55,212-2 inhibits the interleukin-1 signaling pathway in human astrocytes in a cannabinoid receptor-independent manner. J Biol Chem. 2005;280(43): 35797-35806.

131. Khokha R, Waterhouse P, Yagel S, et al. Antisense RNA-induced reduction in murine TIMP levels confers oncogenicity on Swiss 3T3 cells. Science. 1989;243(4893):947-950.

132. Zacchigna S, Zentilin L, Morini M, et al. AAV-mediated gene transfer of tissue inhibitor of metalloproteinases-1 inhibits vascular tumor growth and angiogenesis in vivo. Cancer Gene Ther. 2004;11(1): 73-80.
133. Ramer R, Hinz B. Inhibition of cancer cell invasion by cannabinoids via increased expression of tissue inhibitor of matrix metalloproteinases-1. J Natl Cancer Inst. 2008;100(1):59-69.

134. Blázquez C, Carracedo A, Salazar M, et al. Down-regulation of tissue inhibitor of metalloproteinases-1 in gliomas: a new marker of cannabinoid antitumoral activity? Neuropharmacology. 2008;54(1):235-243.

135. Ligresti A, Moriello AS, Starowicz K, et al. Antitumor activity of plant cannabinoids with emphasis on the effect of cannabidiol on human breast carcinoma. J Pharmacol Exp Ther. 2006;318(3): 1375-1387.

136. Preet A, Ganju RK, Groopman JE. [Delta]9-tetrahydrocannabinol inhibits epithelial growth factor-induced lung cancer cell migration in vitro as well as its growth and metastasis in vivo. Oncogene. 2007;27(3):339-346.

137. Pisanti S, Borselli C, Oliviero O, Laezza C, Gazzerro P, Bifulco M. Antiangiogenic activity of the endocannabinoid anandamide: correlation to its tumor-suppressor efficacy. J Cell Physiol. 2007; 211(2):495-503

138. Portella G, Laezza C, Laccetti P, De Petrocellis L, Di Marzo V, Bifulco $M$. Inhibitory effects of cannabinoid $\mathrm{CB} 1$ receptor stimulation on tumor growth and metastatic spreading: actions on signals involved in angiogenesis and metastasis. FASEB J. 2003;17(12): 1771-1773.

139. Blázquez C, González-Feria L, Álvarez L, Haro A, Casanova ML, Guzmán M. Cannabinoids inhibit the vascular endothelial growth factor pathway in gliomas. Cancer Res. 2004;64(16):5617-5623.

140. Thapa D, Lee JS, Heo SW, et al. Novel hexahydrocannabinol analogs as potential anti-cancer agents inhibit cell proliferation and tumor angiogenesis. Eur J Pharmacol. 2011;650(1):64-71.
Cancer Management and Research

\section{Publish your work in this journal}

Cancer Management and Research is an international, peer-reviewed open access journal focusing on cancer research and the optimal use of preventative and integrated treatment interventions to achieve improved outcomes, enhanced survival and quality of life for the cancer patient The journal welcomes original research, clinical \& epidemiological

\section{Dovepress}

studies, reviews \& evaluations, guidelines, expert opinion \& commentary, case reports \& extended reports. The manuscript management system is completely online and includes a very quick and fair peerreview system, which is all easy to use. Visit http://www.dovepress.com/ testimonials.php to read real quotes from published authors. 